\title{
Consumer rights in halal products: a study based on legal and Syariah perspectives
}

\author{
*Ab Halim, M.A. and Mohd Salleh, M.M. \\ Faculty of Syariah and Law, Universiti Sains Islam Malaysia, Bandar Baru Nilai, 71800 Nilai, Negeri \\ Sembilan, Malaysia.
}

\author{
Article history: \\ Received: 30 August 2019 \\ Received in revised form: 27 \\ January 2020 \\ Accepted: 13 February 2020 \\ Available Online: 26 \\ February 2020 \\ Keywords: \\ Consumer Law, \\ Consumer rights, \\ Consumer protection, \\ Halal Law, \\ Syariah Law, \\ Consumer and Halal
}

DOI:

https://doi.org/10.26656/fr.2017.4(S1).S31

\section{Introduction}

Dismantling of mass media on the abuses in halal's logo and selling of illegal foods as 'halal' in the market in this country from time to time proves this problem is not a new issue. This halal and haram issue stands based on three factors that are Muslim's consumer attitudes towards value of halal and haram foods that they are purchasing, the seller's attitude whether they respect the laws of the Muslim and law enforcement in terms of legal action taken, either sufficient to curb on cheating of halal's logo.

Many Muslims prefer to choose favorite food according to ability, desire and their appetite by just looking at their taste and nutrition that will be obtained without looking into the extent to which it is fit for consumption, especially in terms of hygiene and halal status in accordance with religious tenets. Allah says in Surah Al- Baqarah verse 172:

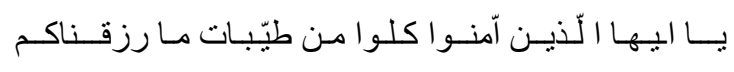

"O you who have believed, eat from the pure things which we have provided you."

The meaning of "pure things" in the verse above includes clean food because when it's clean of course it is also good. Good and clean food will ensure the health of the body. Thus, in addition to choosing nutritious and healthy food, preference should be emphasized on hygiene and purity in terms of religious tenets. As the Prophet says:

$$
\text { إن الله أبى أن يدخل الجنة لحما نبت من سحت فالنار أولى به }
$$

"That flesh will not enter Paradise which has grown from Haram, and all that flesh which has grown from Haram, the fire (of hell) is more worthy of it." (AlHakim)

Islam is concerned about the health of its followers. A faithful person who takes care about cleanliness and purity of food each day, then surely the light of faith will encourage him or her to keep on the hygiene entirely including clothing, shelter, body and so on.

Allah has said in Surah Al- Nahl verses 114 to 115 to 
the effect:

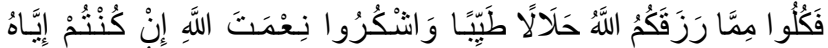

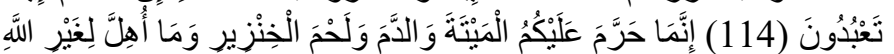

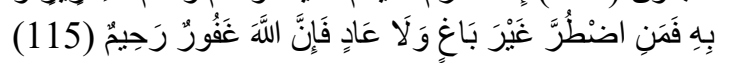

"Eat of what Allah has bestowed upon you from lawful and clean. Give thanks to the bounties of Allah, if you truly worship God. He has only forbidden you carrion, blood, pork and sacrifice, not because of God. So, anyone who had to eat it in, and he did not intentionally look for it, then Allah is Forgiving, Most Merciful."

Halal is an issue that has long been debated, but today, this issue has become increasingly complex as a result of innovation and technology that is rapidly expanding. Halal is also gaining attention not only in Malaysia but it has also expanded globally. The era of Globalization has brought more challenges to the consumer. In Malaysia, the consumer is also facing with consumerism issues and it is not limited in matters of halal products alone. Dishonesty in business practices such as poor quality of the goods, the expensive price of the products, snatch balance, counterfeiting of goods, lack of quality control or standards in merchandise control and other forms of fraud that exists in Malaysia (Ding and Ahmad Yusoff, 2016). Thus, the right of consumers needs to be strengthened.

There is a lot of abuse relating to the use of the halal logo, especially when it comes from the foods and products. The questions are whether Muslims' rights are fully protected under the law relating to halal and what is the rights conferred by law if the producers do not comply with the regulation? For example, a question about the origins of foods or products ingredients and whether or not they are complying with an Islamic requirement, and if it is not, what is the best mechanism to overcome this issue in order to protect the consumer. This paper will study on the rights of the consumer in halal products by referring to the legal statutes and also by discussing at the Quranic verses and Hadith to find out whether the right is stipulated in the statutes and Syara'.

When debating the questions of halal, very wide areas of what accounts as as halal, which include food, halal banking, halal pharmaceutical, halal service financing, halal vacation and so on. However, this paper will only focus on the rights of consumers in matters of consumer foods and products basis exclusively.

\section{The abuse of halal logo}

When halal is mentioned, it is indirectly related to the issue of consumerism. Consumerism is an important issue that cannot be not solved within a country, how can a country looks after the welfare of its people can be seen based on the policies and laws that have been enacted and enforced by the state (Ismail, 2000; Ab Halim, Mohd, Mohd Salleh et al., 2014). It is unfortunate that the Malaysian's market is flooded with various issues such as counterfeited items, misleading advertisement. this As a result, it can cause various problems to the consumer, such as harmful preservative and dyes in foods and medicines that are banned in that developed countries, but are sold in the developing countries such as Malaysia (Ding and Ahmad Yusoff, 2016). The dangers arising from various food products and ingredients do not necessarily have the halal status of the product, and if there is, its status is very questionable in terms of the halalness of the product.

In dealing with the cases of fraud halal logo, it is unfortunate that some business entities which already earned halal logo, they the logo, approval of halal certificate that had been expired or in serious cases, they used fake halal certificates. For example, there was a business that used the halal logo for their products but after the investigations and studies carried out on the product, it was found that the products contain alcohol or deoxyribonucleic acid (DNA) of pork that is forbidden in Islam. Such cases occurred in Malaysia and it has been reported by mainstream media in Malaysia. Some manufacturers fail to display the sources of ingredients if they contain gelatine or emulsifier; the source may derive from a prohibited animal or non-halal ingredient, but the food label may nevertheless be labelled as halal (Ab Halim and Mohd Salleh, 2012).

Among the reported cases was the exposure of the Malaysian Department of Islamic Development (JAKIM) regarding the results of the analysis carried out by Malaysia's Chemistry Department in samples of HP Sauce and Tabasco Pepper Sauce which confirmed the presence of porcine DNA (Utusan Malaysia, 2011d). In Utusan Malaysia (2011a), it was reported that the Muslims were reminded not to use butter from the Golden Churn Pure Creamery Butter brand after the JAKIM confirmed the products were not halal.

In another report, three directors of Rail Passion Sdn. Bhd (Rail Passion) was charged in the Magistrate Court for selling coffee containing pig DNA at the food stall, Kluang Rail Coffee without putting any label about its existence statement on the packaging label of the product (Utusan Melayu, 2011c). Muslims had been advised to be aware in choosing foods on the basis of bread, pastry and cake in the market. This happened after JAKIM had revoked the application of halal certificate of the 
product's manufacturer that supplied non-halal ingredients to some well-known supermarket and restaurant in this country (Utusan Melayu, 2011c).

The former minister in the Prime Minister's Department, Datuk Seri Jamil Khir Baharom has mentioned that a lot of manufacturers of health products available in the market has yet to submit the application of halal certificate to JAKIM or the State Islamic Religious Department (JAIN). And it was only 20 companies of health supplements and 14 manufacturers of traditional medicines in this country that have halal certificate from JAKIM (Utusan Malaysia, 2011b). A study made by the Ministry of Science, Technology and Innovation on 15 samples packed pharmaceutical gelatin capsule taken randomly from the market, three of the products were positive with pig DNA. The presence of DNA was detected by using diagnostic kits developed by a local multinational company through a pilot project jointly with the Ministry because it was an effort to develop halal standard products in Malaysia (Utusan Malaysia, 2011b).

Kopitiam Restaurant which is one of the popular restaurants in Malaysia also had related issues. There still many Kopitiam restaurants in Malaysia refuses to apply for halal certification from JAKIM. Some ingredients are obtained from the dealer who also supplied products to the market and it was identified after JAKIM did an inspection of a Kopitiam which obtain supplies of raw materials dishes from a company producing meat and chicken-based value-added products such as sausages and meatballs, inspection and test results on samples taken found the food served at the Kopitiam contain pig Deoxyribonucleic Acid (DNA) (Md Denin and Ali, 2011).

In the case of slaughtered animals, Royal Malaysian Customs Department (JKDM) Selangor seized a total of 22.750 kilograms of cattle in the form of doubtful halal status frozen meat worth RM342, 150 to be after inspection of a container in the North Port. As a result, the declared container containing cargo carrots showed that only the first three rows in the container containing cargo carrots. Whereas, the Container load balance was frozen cattle meat packed in a box believed to be from Argentina and no halal certification (Utusan Malaysia, 2011b).

During the month of Ramadan in 2010 (1431 H), JAKIM and KPDNKK had made Ramadan Buffet operations ranging from $1^{\text {st }}$ until $28^{\text {th }}$ Ramadan $1431 \mathrm{H}$ and found almost $50(52 \%)$ hotels and restaurants from 96 inspections are reluctant to obey the standard of halal stipulated by JAKIM and JAIN (Abdul Aziz, 2010). Among the findings is the use of alcohol-based on raw materials, the doubtful ingredients, raw materials that had no halal certification, the chicken from unclear sources, the mixing of raw materials with non-halal in the reception area (loading bay), storage and the usage of Malaysian halal logo without a valid halal certification from JAKIM and JAIN (Abdul Aziz, 2010). However, only four cases were investigated under the Trade Descriptions Act 1972 (TDA 1972). This is due to the requirements under the Trade Descriptions (Use of Expression 'Halal') Order 1975 which mentioned that clear evidence of the existence of illegal mixing ingredients in these foods are needed before an action can be made. If the alcohol is to be in-store or in the kitchen alone and not mixed during this inspection, the burden of proof is quite difficult to investigate, it is also the same as chicken or meat that has been cut in his head, but from the point of ruling it clearly raises a reasonable doubt that considered syubhah and it does not comply with halal standards (Abdul Aziz, 2010).

Definition of halal cannot be understood wholly by the industry as the real meaning of the concept of halal. JAKIM had received many complaints from the public as regards to halal status at the food stall belong to nonMuslim who use Quranic verses or other symbols at their stall. Most of the investigation by JAKIM find it difficult to prove that the food prepared was using non halal material. Some of them, using chickens and meats sources from the premises that had no halal certification. In this issue, it is unfortunate that there is no specific law provided to take action against non- Muslim that displaying or hanging up Quranic verses at their stall (Abdul Aziz, 2010)

There were reported cases where mamak restaurants owned by non-Muslims who use Quranic verses and Muslim workers to mislead consumers into thinking that they have halal certification. Action can be taken against the owner of the restaurant in regard to their actions that can confuse the consumers and make them understood it as halal. Based on the cases that have been reported found that there is dishonesty in diapers vendor level to deceive and create false representation to the consumers especially in the use of the halal label is very worrying. However, action taken by the authorities is very difficult to be implemented due to the limited jurisdiction of JAKIM and State Religious Council Department as well as lack of evidence to prosecute. This is clearly an abuse to the consumers especially on Muslim's consumers who desire halal foods and products.

\section{Halal related laws}

Malaysia's commitment in terms of handling of halal products can be seen from the Malaysian Halal Standard 
(MS 1500:2009) in using the guidelines of International Organization for Standardization (ISO)/International Electrotechnical Commission (IEC) Guide 65 and the Malaysian Halal Certification Procedures Manual, Standards, guidelines and manuals have the potential to be adopted by other countries in the world. As a result of widespread campaigns and international forum, the Islamic countries of the Organisation of Islamic Cooperation (OIC) have begun to show interest in adopting the Malaysian halal standard (Abdul Aziz, 2010).

Legal provisions governing halal food production are found in various Acts, regulations, and standards. Laws and regulations concerning halal are important for the protection of consumers - for example, to ensure that halal food manufacturers and traders fulfil their moral and legal obligations towards consumers. The laws, regulations, and standards stand together as a guideline for all Muslim and non-Muslim food manufacturers ( $\mathrm{Ab}$ Halim and Mohd, 2012; Ab Halim and Ahmad, 2014; Ab Halim, Mohd, Mohd Salleh et al., 2014).

However, in the Government's efforts to set the standard halal, a question arises about the extent of things that can be observed by halal food manufacturers in the country.

Thus, the participation of consumers, government agencies and halal industry player are important. This is important in building a halal branding can be achieved in international standard, in fact, capable of providing a high level of confidence to the Muslim community on food products or kosher items, thus helping to give a positive impression to the outside world, especially to non-Muslims about Halal branding. There is general protection provided by law in relation to halal products in Malaysia (Ab Halim et al., 2013). In managing Halal certification by JAKIM and State Religious Council Department (JAIN), a number of laws and the following acts adopted in the monitoring and enforcement: -

1. The Trade Description Act 2011 (TDA 2011), the Trade Descriptions (Halal Definition) Order 2011 and the Trade Descriptions (Certification and Marking of Halal) Order 2011 which explains the definition of halal and kosher food preparation in terms of Islamic law and forgery offences halal raw materials and documents that are enforced by the Ministry of Domestic Trade and Consumer Affairs (KPDNKK) Malaysia;

2. The Food Act 1983 and the Food Regulations 1985 in relation to labeling, food hygiene and safety practices enforced by the Ministry of Health Malaysia $(\mathrm{MOH})$;
3. The Animal Act 1953 (2006 Amendment), Abattoirs (Privatization) Act 1993 and the Animals Rules 1962, Animals (Importation) Order 1962 in relation to animal husbandry and disease control by the Department of Veterinary Services (DVS);

4. The Customs Act 1967 Customs (Prohibited Imports) Regulations 1998 in relation to import halal meat by the Royal Malaysian Customs Department;

5. The Syariah Criminal Offences (Federal Territories) 1997 - Marking halal food by the Department of Religious Affairs;

6. The Local Government Act 1976 and the By-Laws of Local Authorities, and Trademarks Act 1976 by the KPDNKK.

All laws and act on, not subject to the jurisdiction JAKIM. JAKIM halal certifications run using halal standards of Malaysian Standards (MS) and the Malaysian Halal Certification Procedures Manual (Abdul Aziz, 2010). For enforcement purposes, JAKIM depends on the laws and acts of other agencies. This resulted in a law enforcement action less effective. In the use of the halal logo in Malaysia, the amendment of the law against the Trade Descriptions Act 2011 (APD 2011) has allowed only one (1) halal logo can be used; Malaysia Halal logo (Order 3, Trade Description Act, 2011) and for imported food products, only halal logos from operators outside Malaysia are recognized by JAKIM (Order 5, Trade Description Act, 2011). JAKIM will make inspections to operators' overseas halal seeking Malaysia's halal logo to ensure they meet the provisions of the law in force in Malaysia. Without a halal certificate recognized by JAKIM or JAIN, it is an offence under the Trade Descriptions (Certification and Marking of Halal) 2011 which is punishable as follows (Order 8, Trade Description Act, 2011):

i) For individual or corporate, to a fine not exceeding two hundred thousand dollars, and for a second or subsequent offence, to a fine not exceeding five hundred thousand dollars.

ii) For an individual, to a fine not exceeding one hundred thousand ringgit or to imprisonment for a temp [oh not exceeding three years or both, and for a second or subsequent offence, to a fine not exceeding two hundred and fifty thousand ringgit or to imprisonment for a term not exceeding five years or to both.

Based on the above scenario and current development, it can be seen how the right consumers, especially in the halal issue is questionable. This is because the existing law is seen not able to curb this abuse and it is questionable how the consumers are protected in cases of halal matters. 


\section{Consumer rights under malaysian law}

Recognition of consumer's right had been voice out by the former President of America, John F. Kennedy who had introduced 'The Consumer Bill of Rights.' to the citizen in the democratic country (Adnan, 1990). This Bill was introduced after the draft to protect the consumers was presented before the America Congress on 15 Mac 1961 (Adnan, 1990). Four of consumer's right had been declared such as the right to safety, the right to be informed, the right to choose and the right to be heard. After that, International Organization of Consumers Union (IOCU) had received and developed another right that was encouraged by President Kennedy whereas the right to basic needs, the right to environmental health, the right to redress or remedy, the right to consumer education and the right to be represented (Adnan, 1990). This was in line with the speech by Fazal (1982), IOCU President as follows:

"In particular, it is about promoting and protection seven specific consumer rights; the right to have our basic needs met efficiently and equitably...the right to compensation against damage... the right to consumer education, to enable you to be informed consumer throughout your life, the right to a clean environment that permits a life of dignity and well being...".

On 10th April 1985, consumer protection guideline was approved by the United Nations and it was adopted unanimously by members of the UN including Malaysia (Adnan, 1990). The following rights such as follows (Adnan, 1990):

1. Protect consumers from any danger to their health and safety.

2. Promote and protect the interest of consumers.

3. User access to an adequate description to enable them to make informed choices according to individual needs and desires.

4. Consumers education.

5. Provide effective consumer demand.

6. Freedom to form groups or consumer organizations and chances of opportunity to express opinions in the decision making process in order to preserve their interests.

Malaysia has outlined the rights that should be available to the consumer including basic needs, the right to safety, right to information, right to choice, freedom of expression, the right to compensation damages, the right to education, the right to a healthy environment and safe

In debating the rights of consumers in halal products, two main rights, namely, the right to information (this is because the information is often presented to the consumer in halal matters is questionable) and secondly, the right to compensation if deceitful happened in cases that involve halal products.

\subsection{The right to be informed}

It means the right to give the consumers the facts necessary to enable the consumers to make the right choice. This right is essential to avoid fraud and to protect consumers from misleading advertisement, wrongful labeling and unethical of business practice by the producers.

Labeling is important and valuable things for the consumer because it can be used as guidelines by the consumer in making decisions before buying the products. This all depends on the true and accurate information that can be received, information that can be understandable and clear information. A number of laws available to regulate product's labeling such as the Trade Description Act 2011, the Foods Act 1983, the Foods Regulation 1985 and the Price Control (Labelling by Manufacturers, Manufacturers, Importers and Wholesalers) 1980.

In cases relating to halal, there are many issues related to halal fraud including the false labelling and fraudulent matters in Halal (Ab Halim and Mohd Salleh, 2018). Although it has existed law to curb this situation, these incidents keep reoccurring. This might be due to the lawful enforcement of which can only be implemented by the Ministry of Domestic Trade, Cooperatives and Consumerism Ministry is assisted by the Department of Islamic Development Malaysia (JAKIM). This constraint may also be due to too many cases, while enforcement officers are limited.

In the Sale of Goods Act 1957, there are implied terms will apply if there are no real terms between seller and buyer. Between the implied terms can be applied in label counterfeiting issues halal or halal abuse is a provision that the implied condition exists that the actual sale of goods shall be equal to or coincide with the description given (Section 15, Sale of Goods Act, 1957). If the seller fails to provide the same items as described, the buyer has the right to reject the goods (Section 12, Sale of Goods Act, 1957). On the issue of abuse of the halal label, the buyer has the right to make a claim if the seller is found by the authorities to have abused the usage of the halal label.

\subsection{Right to be compensated}

It means the right in solving the claim whereas this right had generally acceptable since yer 1970 and it involves the right to seek redress towards non-quality 
products and services (Adnan, 1990). In halal products context, if misappropriation happened in the context of halal products such as abuse of halal's labels, consumers had right to seek compensation based on the indirect terms between seller and buyer as provided in Section 15, Sales of Goods Act 1957. Besides this Act, the other applicable laws that can be used on claiming remedies are Contracts Act 1950, Trade Description Act 2011, and Consumer Protection Act 1999.

\section{Consumer's right in Islamic law}

Generally, consumerism in Islam refers to someone that obtain goods or service to fulfill his or her necessities besides to reach the valid aims in Syara' (Karim and Hamid, 2009). In the sale and purchase transaction, Islam is very concerned about quality and right of a consumer. Goods quality that was sold were guaranteed. The consumers' satisfaction is the consideration towards the price that they had paid. Besides that, halal aspect was vital because it was related with the question of fulfilled religious order. Among the consumer's rights that need to stressed are as follows:

\subsection{Right to get the pure and quality foods (halalan toyyiba)}

In surat Al-Baqarah, verse 168, Allah stated that:

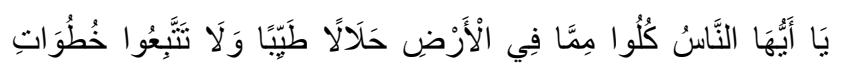

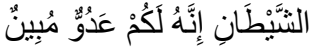

Meaning: "O people, eat of the lawful and good on the earth, and follow not the footsteps of Satan, for surely he is an open enemy for you".

In the above verse, Allah had ordered Muslims to consume pure foods and avoid from following satan's order. This verse is an order from Allah that is compulsory to be obeyed by the Muslims.

Al-Jurjani in Kitab al-Ta'rifat (Al-Jurjani, 1985) explained that the purpose of the halal refers to the permissibility of using objects or anything that is required to meet the physical needs such as food, beverages and medicines. Halal also connected with the necessity harness, eating, drinking and doing what is permissible based on the texts.

In the Qur'an, Allah uses the term halal in various conditions of a sentence. The example can be seen in Muamalat matters, family and marriage issues, food and others. What is more interesting about the concept of halal food and sustenance mentioned in the Quran is the adjective of "toyyib". At-Tobari (1405) explained the term "Toyyib" indicate a clean, quality, not unclean and forbidden to eat.
The consumer deserves to get halal and quality foods because this is a concept that is abiding by all Muslims (Mohd Salleh et al., 2019). The manufacturers of the products must make sure that the foods that are manufactured in line with the principles of halal and toyyib. In addition, it is also to ensure the blessings offered in life (Ab Halim, Mohd Salleh, Kashim et al., 2014). So it is the duty of every Muslim man and society to ensure that these claims are met. The process of preparation of halal food and drinks from preparing the raw material until it is served on the table must be complied by every Muslim who is involved in the business of food and beverages.

\subsection{Manufacturer must manufacture the best product for the consumers}

Islam outlines that manufacturers must obey the principles of halal and toyyib, and to not only think about profits but eagerly obey the religious order. Foods that are manufactured must be free from any unlawful elements and they must make sure the products come from good quality.

In a hadith, the Prophet SAW said to the effect:

$$
\text { إن الله يحب اذا عمل أحدكم عملاً ان يتقنه }
$$

"Surely God loves when any of you does an endeavor that he seeks to perfect it". (al-Tohrani)

Based on the word 'itqan' or endeavor in the hadith above, the manufacturers need to ensure that their products are in good quality and the ingredients used was allowed by Syara'.

The sellers must not deceit the consumers by putting the halal logo even the ingredients are not halal. If this situation happened, Islam gives the right to the consumers to claim for compensation due to the flaws ('aib) on the products or the consumer can request for replacement of the produces due to the broken or flaws with another item. The right to exchange the goods is known as khiyar will be discussed at the end of the discussion.

\subsection{Getting right to information about the products}

A consumer deserves to know and choose the best quality of necessary items for him or her. Among matters that is compulsorily needed to know by a consumer is the price of the item, the expired date and the contents of the products. In some circumstances, consumers also need to know how to use the products or items correctly. Thus, the manufacturers and the sellers are obliged to expose all the information in the packaging of the products.

Islam provides guidelines as the ethics in sale and 
purchase transaction to ensure that the buyers and consumer rights are guaranteed. Among them, the manufacturers and the sellers must not deceit, not honest and irresponsible in giving information about the products and hiding the goods for the intention to get higher profits (ihtikar). In a hadith that narrated by Abu Hurairah r.a., the Prophet said that:

$$
\text { ومن غشنا فليس منا }
$$

"He who cheats does not belong to us "(Muslim)

Besides that, Al-Quran also stressed on the sellers and manufacturer's responsibility of being honest in their business such as not to cheat buyers in the measurement. Allah stated in Surat Al-Israk, verse 35:

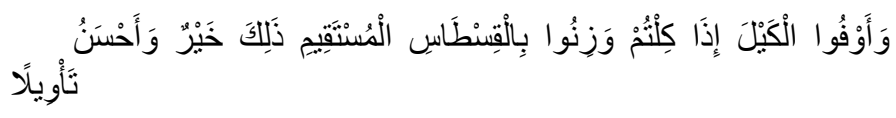

Meaning: "And give full measure when you measure, and weigh with a balance that is straight. That is good (impact for you in the world) and better outcome (that is the reward in the Hereafter)"

In Surat Al-Mutaffifin, verse 1 to 4, Allah said:

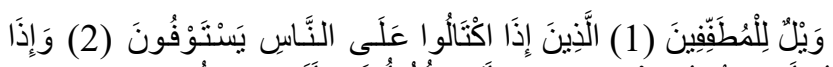

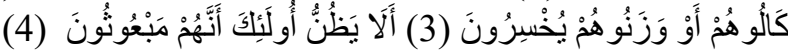

Meaning: Woe to those that deal in fraud. Those who, when they have to receive by measure, from men, exact full measure. But when they have to give by measure or weight to men, give less than due. Do they not think that they will be called to account?"

In a wider scope, the above verses remind on the importance of being honest and fair in business. Thus, a manufacturer cannot mislead the buyer by giving unclear information. Therefore, the information given must be stated clearly, correct and in details.

5.4 The right to good exchange because of the flaw (khiyar 'Aib) and get compensation (Dhoman) when being deceit.

Islam protects consumer by giving the right to choose (khiyar) and to change the defective good sold by manufacturers. There are seven types of khiyar in Islam , which are as follows; khiyar syarat, khiyar ta'yiin, khiyar ru'yah, khiyar 'aib, khiyar majlis, khiyar ghubun dan khiyar tadlis.

\subsubsection{Khiyar 'Aib definition}

Khiyar 'Aib is the right to cancel or continue the contract if it is proven that there is disgrace (defect) in the product, while the buyer does not know about it at the time the contract lasts. Or, in another words, if someone buy a defective good and did not know about this until the seller and the buyer separated, then the buyer deserves to return back that good to the seller (AlKhalafi, n.d).

Syaikh Shalih ibn Fauzan (n.d) explains khiyar aib is khiyar as between the purchaser because of the flaw and defective good that was not mentioned by the seller or unknowing by him, but such flaw is clear on the trade good before it was a sale. The right to choose is owned by each of the parties involved in the contract (transaction or agreement) to cancel the contract if such an article was crippled in a previous transaction is not known. In determining disability khiyar allows for this, according to the sect Syafi'iyah are all things that can be seen recede from articles intended or absence of the intended goods, such as shoes narrow, cutting off the ears or horns of animals will be sacrificed (Al-Zuhaili, n.d).

The defects that cause the emergence of khiyar, according to scholars of Hanabilah are all elements that undermine the object and reduce its value selling by traders' tradition like a boy who 'castrated' although their prices are not reduced, and maybe getting more expensive value. Or the presence of defects that cause a reduction in the price or value of the goods in the tradition of the merchants, although the object transactions (buying and selling goods) did not experience a price reduction (Al-Zuhaili, n.d).

\subsubsection{Legal basis of Khiyar Aib application}

Hadith narrated from Uqbah ibn Amir Radhiyallahu' Anhu, he said, I heard the Prophet SAW said (which means):

لَ

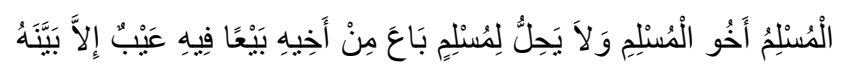

"Fellow Muslims are brothers, not permissible for a Muslim to sell their goods to other Muslims, even though the goods are disgrace / disabled". (Narrated by Ibn Majah, Ad-Daraquthni, Al-Hakim dan Ath-Thabrani. Ibnu Hajar Al-Asqalani said in Fathul Bari, "Isnaads jayyid (nice)" (Al-Haithami, n.d)

And, another narration, from Abu Hurairah Radhiyallahu 'Anhu that the Prophet SAW said:

$$
\text { مَنْ غَشََّ فَلَيْنَ مِنَّا }
$$

"He who cheats does not belong to us "(Narrated by Muslim) (Maktabah Syamelah, n.d).

In khiyar aib the buyer has two options either she 
willingly and is satisfied with the items to be purchased. If she is willingly, even she knows about the defect on the item, then khiyar does not applied and she must accept such item. In contrast, if she rejects and returns the goods to the owner, then the contract is null or in other words, there is no transaction.

When buyers know disgrace after the contract, then he is entitled to make khiyar whether to proceed with the purchase and taking of damages as the difference between the price of the quality good and the price of disgrace good, or for him to cancel the purchase and return the goods and ask for return of the money paid. However, if the buyer is aware of defective when receiving the goods, then there is no khiyar for him and contracts (transaction) has often happened, because he will be considered pleased and receive such defective (Maktabah Syamilah, n.d).

Khiyar aib is there since the emergence of the defect even contract has lasted long enough. About cancellation of the contract after note that there is impaired either directly or postponed, there are two opinions as follows:

First Opinion: Scholars Hanafiyah and Hanabilah are of the opinion that nullifying the contract after note that there is a delayed defect, which is not directly required (Wahbah Zuhaili, n.d).

Second Opinion: The scholars of Syafi'iyah and Malikiyah are of the view that the cancellation of the contract must be done after knowing the impairment, i.e. directly according to the custom and it cannot be postponed. However, it is not considered to postpone if punctuated by prayers, eat and drink. Among the reasons is that the persons in the contract do not suffer harm, and ending the contract is common (Wahbah Zuhaili, n.d).

Some conditions that may hinder cancellation of the contract and return the goods:

Perhaps start with According to Wahbah Zuhaili, if the following condition occurs, the contract might be cancelled and the goods might be returned to the sellers

Acceptance after knowing about disabilities, either spoken or availability of clear guidance.

Dropping Khiyar, either express or availability of guidance. As a purchaser said, "I have to drop khiyar (vote) me", and similar speeches.

Goods damaged from the act of the buyer or changed from its original form.

Additional availability of the items together with the goods and is not derived from or additional separate origin of the goods, but is derived from the original, such as the appearance of the fruit or the birth of children (Wahbah Zuhaili, n.d).

The problem occurs when the buyer and seller who are in conflict on whom the aib happens and no qorinah (sign/evidence) that strengthens one of them then the seller's words are accepted based on the hadith:

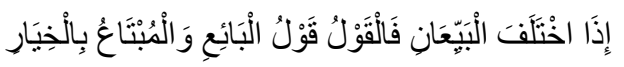

"When the seller and the buyer in conflict then the accepted word is the word of seller, while the buyer has the right to select". (HR. At-Tirmidzi III/570 no.1270, dan Ahmad I/466 no.4447. And in authentic by Syaikh Al -Albani dalam Irwa' Al-Ghalil no: 1322) but it must be accompanied by an oath for the Prophet (S.A.W):

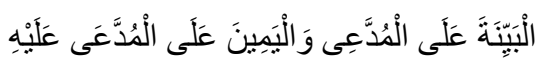

"Al-Bayyinah (bring proof) on the accuser and the accused must swear to that." (Narrated by Bukhari and Muslim V/167 IV/300, from the hadeeth of Ibn 'Abbas).

Based on the above it can be seen that Islam comprehensively protect the rights of the consumers and it is a good effort if all the rights outlined by Islam can be harmonized together civil law towards strengthening the rights of consumers, particularly in aspects of these products.

\section{Conclusion}

Halal and haram of the goods marketed in this country is a sensitive issue for the Muslim community, especially when Malaysia is recognized as one of the Islamic State as mentioned in Article 3 of Federal constitutions. Malaysian Law and Islamic Law has comprehensive provisions to ensure that consumers are protected from any fraud. The sensitivity of the consumers not only on the quality of the products and services that have halal's quality, but even non-Muslims had also accepted on the halal products and services increasingly. Some suggestions are presented here are to ensure the rights of the consumers, especially the halal products are always protected. However, the most important thing to do is to ensure law enforcement runs smoothly. The law is there but needs enforcement. In addition to the above, the role of each of the parties involved, namely the government, suppliers, manufacturers, traders, consumer associations, NGOs and consumers themselves must play a role to ensure that the perversion of halal products can be eradicated and thus preserve the right of consumers to obtain products really clean and halal. Government is responsible for protecting consumers from fraud or abuse in halal products. Therefore, it is important for the government to ensure that the existing laws are enforced properly and if 
there is lacuna in the law, then the laws must be reviewed and improved in order to produce a set of laws that really works and effective and can be achieved on the optimal level of consumer protection. For example, the burden of proof of food or products containing illegal material is difficult to prove. This resulted in a difficulty to initiate legal proceedings to the offender. The government should also ensure that law could be served as a medium in protecting consumers in using halal products and users can also deal and have easy access to their rights that may be null arbitrarily been misled by those who abuse the halal label for easy profits. For the suppliers, manufacturers and merchants, they need to comply and follow the existing laws that have been set regarding the rights of consumers. They need to work together to protect the rights of consumers by means of honest labeling so that consumers can make check and make a choice. They cannot pursue profits simply by denying the right of consumers to know whether a product is really halal or not. Consumer associations and non-governmental organizations (NGOs) should also play a role in carrying out the study, gather information on halal products and further disseminate the information to the user through the effective medium of mass media, writing and expressed to the authorities to ensure that appropriate action is taken to safeguard the rights of consumers. Consumers should also play a role in their rights to obtain these products. If consumers were deceived, then they should take prompt action to bring the relevant parties to justice so that it serves as a lesson to other parties. This in turn can help reduce malpractice cases in these products.

\section{Acknowledgement}

This article is a research being conducted by the authors with the use of research funds by Institute of Halal Research and Management Universiti Sains Islam Malaysia under research code (PPPI/ KHAS_IHRAM/03/051007/13718).

\section{References}

Ab Halim, M.A. and Ahmad, A.A. (2014). Enforcement of consumer protection laws on halal products: Malaysian experience. Asian Social Science, 10(3), 9 -14. https://doi.org/10.5539/ass.v10n3p9

Ab Halim, M.A. and Mohd Salleh, M.M. (2012). The Possibility of Uniformity on Halal Standards in Organization of Islamic Countries (OIC). World Applied Science Journal.

Ab Halim, M.A. and Mohd Salleh, M.M. (2018). Peranan Jakim Dan Jain Dalam Kes Yang Melibatkan Penyalahgunaan Label Halal Pada Produk Makanan. Malaysian Journal of Syariah and
Law, 7, 51-60. [In Bahasa Malaysia].

Ab Halim, M.A. and Mohd, K.W. (2012). Keberkesanan Penguatkuasaan Undang-Undang Berkaitan Produk Halal Bagi Perlindungan Pengguna presented at Proceedings of Seminar Persidangan Fiqh Muamalah dan Isu-isu Fiqh Semasa 2012. UKM, Malaysia: Faculty of Islamic studies. [In Bahasa Malaysia].

Ab Halim, M.A., Mohd Salleh, M.M., Kashim, M.I.A.M., Ahmad, A.A. and Nordin, N. (2014). Halal pharmaceuticals: legal, shari'ah issues and fatwa of drug, gelatine and alcohol. International Journal of Asian Social Science, 4, 1176-1190.

Ab Halim, M.A., Mohd, K.W., Mohd Salleh, M.M., Yalawae, A., Tuan Syed Omar, M.N.S., Ahmad, A.A. and Kashim, M.I.A.M. (2014). Consumer protection of halal products in Malaysia: a literature highlight. Procedia-Social and Behavioral Sciences, 121(19), 68-78. https://doi.org/10.1016/ j.sbspro.2014.01.1109

Abattoirs Act (Privatization) 1993. Act 507. (MY).

Abdul Aziz, W.M.S. (2010). Keberkesanan UndangUndang dan Penguatkuasaan Mengenai Makanan dan Produk Halal di Malaysia presented at Prosiding Seminar Kebangsaan dan Undang-Undang Peringkat Kebangsaan 2010. Malaysia: Faculty of Syariah and Law. [In Bahasa Malaysia].

Adnan, M.H.H. (1990). Hak anda sebagai Pengguna. Petaling Jaya, Malaysia: Penerbit Fajar Bakti Sdn Bhd. [In Bahasa Malaysia].

Animals (Importation) Order 1962. (MY).

Animals Act 1953. Act 657. (MY).

Customs Act 1967. Act 253 (MY).

Ding, C.Y.J. and Ahmad Yusoff, S.S. (2016). Perkembangan Perlindungan Pengguna: Cabaran dan Hala Tuju Institusi Pelindung Pengguna di Malaysia. Malaysian Journal of Law and Society, 20, 71-82. [In Bahasa Malaysia].

Fazal, A. (1982). What the Consumer Movement is about? Presented at Seminar on Law, Justice and the Consumer. Pulau Pinang. Malaysia: Persatuan Pengguna Pulau Pinang.

Food Act 1983. Act 281. (MY).

Food Regulations 1985. Act 281. (MY).

Ismail, R. (2000). Keselamatan Produk dan Perlindungan Pengguna: Satu Tinjauan. Malaysian Journal of Law and Society, 4, 53-73. [In Bahasa Malaysia].

Karim, A. and Hamid, F. (2009). Himayatul Mustahlik Wa Huququhul Insaniyyah Fi As-Syariah Wal Qanun. Retrieved on November 2, 2011 from website: http://www.burathanews.com/ news_article_67851.html pada 2 November 2011. 
Local Government Act 1976. Act 171. (MY).

Md Denin, M.J.A. and Ali, K. (2011). Kopitiam tak peduli. Retrieved on July 10, 2019 from My Metro website: http://www.hmetro.com.my/articles/ Kopitiamtakpeduli/Article/. [In Bahasa Malaysia].

Ministry of Domestic Trade and Consumer Affairs Malaysia (2019). Lapan hak-hak Pengguna yang Asas. Retrieved on July 16, 2019 from Ministry of Domestic Trade and Consumer Affairs Malaysia website: http://www.kpdnkk.gov.my/web/guest/ pengguna/hak-pengguna. [In Bahasa Malaysia].

Mohd Salleh, M.M., Ab Halim, M.A. and Aziz, S.A. (2019). Perlaksanaan sertu kontemporari dalam industry halal. In Ali, A.A.M., Mat, S.R., Sulaiman, S., Mohd Anas, M.M.A., Ariffin, H.S. and $\mathrm{Ab}$ Rahman, A. (Eds.) Contemporary Issues: Islam and Science. Nilai, Negeri Sembilan, USIM. [In Bahasa Malaysia].

Syariah Criminal Offences (Federal Territories) 1997. Act 559. (MY).

The Customs (Prohibition of Imports) Order 1998. Act 1967 (MY).

Trade Description Act 2011. Act 730. (MY).

Trade Descriptions (Certification and Marking of Halal) Order 2011. Act 730. (MY). Retrieved from http:// www.federalgazette.agc.gov.my.

Trade Descriptions (Define of Halal) Order 2011. Act 730. (MY). Retrieved from http:// www.federalgazette.agc.gov.my.

Trademarks Act 1976. Act 175 (MY).

Utusan Malaysia. (2011a). Golden Churn Pure Creamery Butter tidak Halal. [In Bahasa Malaysia].

Utusan Malaysia. (2011b). Sijil Halal Kerajaan Perlu Tegas. [In Bahasa Malaysia].

Utusan Malaysia. (2011c). Tiga Pengarah, Pengilang Kopi DNA Babi didakwa. [In Bahasa Malaysia].

Utusan Malaysia. (2011d) Jakim sahkan HP Sauce, Tabasco Pepper Sauce mengandungi DNA babi. [In Bahasa Malaysia]. 